L. S. Koriashkina ${ }^{1}$, Cand. Sc. (Tech.), Assoc. Prof., orcid.org/0000-0001-6423-092X, O. V. Deryugin', Cand. Sc. (Tech.), Assoc. Prof., orcid.org/0000-0002-2456-7664,

S. O. Fedoriachenko ${ }^{1}$, Cand. Sc. (Tech.), orcid.org/0000-0002-8512-3493,

S. I. Cheberiachko ${ }^{1}$, Dr. Sc. (Tech.), Prof., orcid.org/0000-0003-3281-7157,

M.A. Vesela ${ }^{2}$, Cand. Sc. (Tech.), orcid.org/0000-0001-9318-9110
1 - Dnipro University of Technology, Dnipro, Ukraine, emaill: serg.fedoryachenko@gmail.com

2 - Kharkiv National Automobile and Highway University, Kharkiv, Ukraine

\title{
ON DETERMINING PRODUCTIVE CAPACITY OF EV TRACTION BATTERY REPAIR AREA
}

Purpose. To ensure the effective functioning of the area for diagnosis and repair of tractive electric vehicle (EV) battery by determining the technical and economic indicators of the production capacity of the enterprise.

Methodology. Modelling the process of repairing section of the EV traction battery is performed using the main principles of the queuing system, the graph theory. While calculating the probability-time characteristics and determining the production capacity of the site, the methods of mathematical statistics and probability theory were involved.

Findings. With the use of systematic approach, the EV market in Ukraine and the dynamics of the demand over the past three years have been studied. There was collected and analyzed information about issues related to the EV operation, and the most common ones were identified. Empirically, there was obtained an estimate for the duration of the process of repairing and replacing the EV traction battery, as well as the cost of basic operations. The battery repair section of the traction battery is represented as a multichannel queuing system, assuming that the flow of applications for diagnosing and repair is Poisson's flow, and the random process is Markovian. The problem of rational organization of the EV traction battery repair site has been solved by determining the minimum number of repair posts, at which the queue will not grow indefinitely (if customers can wait for their service for a long time and do not leave the queue). The number of repair posts was estimated for the traction battery, which in the existing conditions will allow organizing technical customer service effectively, minimizing the total economic losses from downtime of process equipment and refusals of applications for repairs.

Originality. The use of models and methods of the queuing system for the calculation of technical and economic indicators of the production capacity of the traction battery repair section allowed taking into account the stochastic nature of the needs for repaire, and determining the optimal values of those characteristics that ensure the efficient performance of the EV repair section.

Practical value. The proposed method for determining the production capacity of the repair section of traction battery is used in solving problems related to the selection and rational placement of technological equipment when designing or upgrading a workshop.

Keywords: electric vehicle, production capacity, repair area, system of mass service

Introduction. Modern EV took its own weighty position in the fleet of vehicles, which are used to meet the needs of transport services of people in full volume. This process is developing and progressing. It is much likely that in the future there will be a complete replacement of vehicles using organic fuel with an automobile with an electric energy source. We can already state the fact that there are a number of countries that have declared in their development strategy complete refusal of the operation of motor vehicles with gasoline, diesel engines, as well as engines using CNG, LPG fuels. Among such countries are Norway, Great Britain and others, where this intention is declared at the legislative level.

It should also be emphasized that well-known world car manufacturers in their turn also carry out EV policy, reorienting their own production for the EV development and production. Well-known automotive concerns - Volvo (from 2019), Peugeot (from 2025), Hyundai (from 2021), General Motors (from 2023) are gradually abandoning the production of cars that use organic fuel and reorient their own production for EV production and plug-in hybrids.

Such process is inevitable. It is requirement of time and understanding of the expediency of transition to more favorable and environmentally friendly energy sources in order to preserve our planet for future generations and, of course, in the nearest future, these changes will primarily affect the cars that are in personal usage, as well as urban passenger and mu-

(C) Koriashkina L.S., Deryugin O. V., Fedoriachenko S. O., Cheberiachko S. I., Vesela M.A., 2019 nicipal transport. And with the development of scientific approaches and production technologies, EVs will gradually become the major vehicles in the transportation performance.

Despite the relatively high commodity price in comparison with analogues that work on organic fuel, and the limited range of traction battery (an average of 200-300 km), the benefits of EVs, which are ecological and economical, cause the growth in their popularity.

Today in Ukraine there is a high demand for EVs. From January till March 2018, according to the data of the IRS Group, the number of EVs in Ukraine increased by $14 \%$ to 801 units. From 2016 till March 2018, there were 6558 electric vehicles registered in Ukraine. The average age of registered EVs in Ukraine is currently 4-5 years. About two thirds of all EVs are registered in three regions: Kyiv (including the capital), Odesa and Kharkiv. Among the brands, the sole leader is Nissan with its Leaf model, followed by Ford Focus, Tesla Model S, BMW i3 and other car makers. Fig. 1 shows the analysis results of the EV sales in Ukraine per March 1, 2018, according to the IRS Group.

The analysis of EV sales statistics in our country shows that a significant segment of sales is EVs from the secondary market coming from the US, the European Union. Of course, this is due to high prices of major EV manufacturers for their products, as compared to analogue cars that work on organic fuels. So, the minimum cost of the EV model "Tesla Model X" is $76,700 €$.

The success of EV sales among consumers is inextricably linked to the quality service and repair organization. This service 


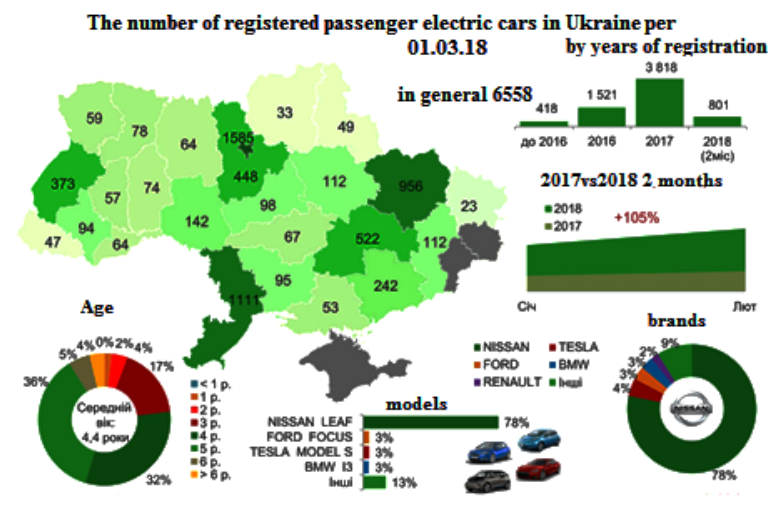

Fig. 1. EV sales analysis per 01.03.2018 by "IRS Group”

can only be provided by authorized dealers that have modern stations for maintenance of the dominant EV brands, possess appropriate diagnostic software and the necessary special tool for repair work. Among such dealerships the following can be highlighted - BMW, Mitsubishi, Nissan, Renault, Tesla, etc.

In order to identify the most common problems associated with the EV usage, the authors have surveyed 1730 owners of Nissan Leaf. The results of failure analysis are presented in Fig. 2.

Thus, the largest failure part, namely $60 \%$, is a problem of traction battery capacity loss. Running second is body repair (20\%) (breakages received during transportation to their destination, road accident, etc.). The third-biggest problem $(10 \%)$ is braking system repair. Five percent of the owners complain about suspension system problems. Other problems are related to the operation of the EV (repair of plug-in connector, air conditioning system, replacement of the cabin filter, lighting devices, etc.). And with the problem of traction motor, there are around $5 \%$ of all complaints.

Since the traction battery is the most important element of the EV in terms of repair effect, it requires a more rigorous approach to operation requirements. This work is devoted to the solution of the diagnostic and repair problem of the EV traction battery due to the determination of the parameters of the service production capacity.

The criteria for the effectiveness of the service area and the repair of the EV selected is its throughput. The disclosure of paramet"ers that affect this indicator, the rationale for their rational selection is the main task that is solved in this paper. Estimation of the EV repair area capacity allows predicting the profits that can get the service, satisfying the customers' needs, predicting an increase in the client base due to the timely provision of relevant services.

Literature review. In the study of vehicles, technical maintenance systems using different methods can be divided into three groups: the simplest, simulation, and analytical ones.

The simplest methods are analogy and destination method. They are used to set operating modes in the absence of empirical information about vehicle maintenance [1]. The application is based on various heuristic rules, the final result of which is approximate and depends on the qualifications and

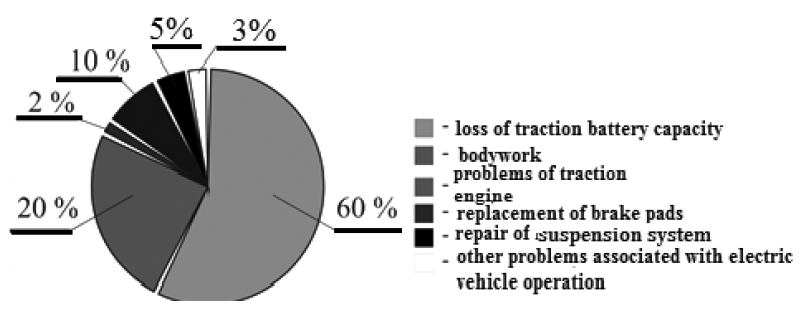

Fig. 2. Failure structure of electric vehicles (Nissan Leaf) by IRS group advances in expertise, which determines the optimal mode. For example, in [2], there is obtained a dependence of the vehicle charging time on the technical capabilities of a solar cell station from which the optimal parameters are selected, which, in their turn, define the cost of the station. However, the conclusions made in the article concerned only the photovoltaic system, the indicators of which depend on the season, weather conditions and other constituents, which stipulate certain limitations of this study. Similar conclusions can be made by analyzing other station types, for example $[3,4]$ devoted to the study of the possibility of rapid charging of EVs from alternative sources. The established indicators require additional inspections during the operation of the stations. It should also be noted that in the above-mentioned works, there is no information regarding the full cycle of EV services.

Imitation methods are more complex in their implementation and require a significant amount of statistical information that is collected during the process of technical exploitation. Their advantages include the possibility of using mathematical apparatus in the processing of statistical data, the ability to take into account a significant number of external factors that affect the object of research [5]. Thus, in [6] the method for determination of some indicators of the production capacity of a technical service is presented based on the probabilistic method, namely: the number of places in the queue, the number of service posts, etc.

Analytical methods are based on the basic laws of cars technical operation [7]. In this group of methods for determining the optimal frequency of maintenance, one can distinguish the following: the method determining the frequency of maintenance to the permissible level of reliability, economic method, econometric probabilistic method, the method for determining the optimal periodicity of the inspection to the allowable value, as well as the laws of changing the parameter of technical condition.

In determining the optimal periodicity of maintenance, it is advisable to organize it so that the values of the criteria that characterize the efficiency of the service, are within certain limits. That is, you need to know the dependence of these criteria on the timing of maintenance work [8]. In [9], although the analytical modeling of the charging station is carried out, however, neither the number of cars that require service during the day nor the possible uneven loading is taken into account.

Comprehensive approach to solve the problems of increasing the efficiency of maintenance systems using different methods will allow obtaining mathematical models to calculate the requirements in the number of service lines, and the parameters of the load of repair equipment.

Most domestic and foreign scientific publications are related to the organization of charging EV stations, research on the rational allocation of such services, as well as the definition of their capacity. In the mathematical modeling of the work of such stations, the queuing system is widely used. For example, in [10], statistical methods are used along with optimization methods to determine the amount of process equipment that can help satisfy demand and minimize production costs. Some studies have been conducted to detect the dependence of system parameters such as queue length, standby time, and various parameters of the EV charging stations of two types - with fast and slow charging. Mathematically, the following conclusion was substantiated: the smaller the station is, the faster battery should be charged. The authors use the standard $\mathrm{M} / \mathrm{M} / \mathrm{c} / \mathrm{N}$ mass maintenance model to describe the process of charging the traction battery of the EV and the analysis of the power stations at the service system queue. Similarly, this approach was used in [11], which describes the methodology for calculating the production capacity of a technical service enterprise.

Therefore, the main purpose of each modern service is to maximize income from the repairs of the relevant vehicle segment. The customers' satisfaction is achieved through the organization of an effective repair service, which is based on the use of modern repair technologies, modern repair equipment, 
the presence of highly qualified staff and a wide range of repair services. The effective operation of the EV traction battery is supported by the planned diagnosis and fails errors check that arise during the operation, in the form of repair work in the area for diagnostics and repair of the EV traction battery, including a set of repair works to replace those battery units, which have lost capacity to critical level.

In case of accidental loading of the service the flow of applications for repair work thickening or dilution happens. Thickening leads to either service deny or queuing. Dilution is the cause of the unproductive (loss-making) stagnation of individual posts in the respective site, and, at the same time, the stagnation of repair equipment and the lack of profit from repair activities. Consequently, EV service is a typical queuing system (QS), and the corresponding mathematical apparatus is used to study the technical and economic indicators of its activity [12, 13].

The purpose of the research is to determine the production capacity of the traction battery repair section, which would ensure the efficient organization of the work of the service for the provision of quality services; development of recommendations for the efficient construction of service, the rational organization of its functioning, the regulation of the flow of applications for the replacement of EV traction battery; the profit from the implementation of this activity, reducing the cost of simple process equipment.

The object of the study is a service station repair section for servicing and diagnosing the traction battery of the EV.

The subject of the research involves mathematical models of the system of service with the finite number of applications, methods and algorithms for calculating their probabilistictime characteristics.

The main method of research is mathematical modeling using the queuing system, the theory of graphs, mathematical statistics, probability theory, the theory of differential equations.

To achieve this goal, the following tasks must be solved:

- to analyze the parameters of the QS, namely: the nature of the flow of applications, the number of channels, their performance and rules of operation;

- to establish acceptable values of the characteristics that affect the production capacity of the technical service enterprise: the number of posts in the area of repair of the EV traction battery; carrying capacity of the traction battery repair station; the number of places in the car park to wait for their turn;

- to evaluate the efficiency of the QS, to find the optimum number of posts for diagnosing and repairing the EV traction battery, which provides the minimum total losses from the simple posts and the failure of applications received.

Let us consider the process of EV repair service. We will assume that the flow of applications for maintenance is stationary, that is, its probabilistic characteristics do not depend on time and $\lambda$ is the intensity of the incoming flow of applications. Of course, this does not mean that the actual number of applications per unit time is unchanged, the flow is not regular and has condensation and dilution. But we will assume that these condensations and dilutions are not regular, and the average number of events occurring in a unit of time is constant. The flow of requests for diagnosing and repairing the traction battery of the EV has no aftereffects, since the events forming the flow appear independently of each other, and each event has its own causes [14, 15]. The flow of applications is also common, because the probability of getting into two or more events for a small period of time is very small compared with the probability of one event being hit. Consequently, the flow of applications for the diagnosis and repair of traction battery can be considered as Poisson. In addition, we will assume that this random process is Markov, for which the prehistory can be neglected. Flow of service - the flow of applications served by one continuously occupied channel - will also be considered simplest, with the average service time $\bar{t}_{o b}$ reversed to the intensity of service $\mu: \bar{t}_{o b}=1 / \mu$.

Depending on the mathematical description of the EV service system for the diagnostic and repair of the traction battery, the criteria for optimizing the efficiency of its operation will be formulated $[16,17]$.

First, let us consider the station for diagnosing and repairing the traction battery as a multichannel system with failures (the classical Erlang problem) [18, 19], which contains $n$ service posts, and find the limiting probabilities of the states of the system, as well as indicators of its efficiency, among which: $A$ is absolute QS pass rate; $Q$ is relative $\mathrm{QS}$ pass rate, that is, an average share of applications received and serviced by the system; $P_{r e j}$ is the probability of a refusal, that is, that the application will arrive, but will leave the system without providing it with the service; $\bar{k}$ is the average number of occupied channels.

The state graph of such system is shown in Fig. 3.

The average number of applications received in the average service time of one application is expressed by the load factor $\rho=\lambda / \mu$. In the queuing theory, the value is also called the aggregate intensity of the flow of applications, or the intensity of one channel load.

The boundary probabilities of open queuing states without queue are calculated according to Erlang's formulas

$$
p_{0}=\left(\sum_{k=0}^{N} \frac{\rho^{k}}{k !}\right)^{-1} ; \quad p_{k}=\frac{\rho^{k}}{k !} \cdot p_{0} ; \quad k=\overline{1, n} .
$$

The probability of a system failure is the marginal probability that all system channels will occupy

$$
P_{r e j}=\frac{\rho^{n}}{n !} p_{0}
$$

The relative and absolute QS throughputs are calculated according to the formulas

$$
Q=1-P_{r e j}=1-\frac{\rho^{n}}{n !} p_{0} ; \quad A=\lambda q=\lambda\left(1-\frac{\rho^{n}}{n !} p_{0}\right) .
$$

The average number of occupied channels is

$$
\bar{k}=\sum_{k=0}^{n} k p_{k},
$$

where $p_{k}$ is boundary probabilities of states, calculated by the (1). Since each busy post serves on average $\mu$ applications per unit time, then

$$
\bar{k}=\frac{A}{\mu}=\rho\left(1-\frac{\rho^{n}}{n !} p_{0}\right) .
$$

Estimation of the section on diagnostics and repair of traction battery efficiency (in the absence of queue) can be carried out according to different criteria of optimality. In the framework of this work, we will set the following two optimization tasks: 1) to find the minimum number of posts in the section, which would provide an average of at least $90 \%$ of applications coming to the service; 2) to find the optimal number of posts in the district, in which the proceeds from the execution of applications as much as possible would cover the loss from idle posts [20]. If the income condition from the exploitation of

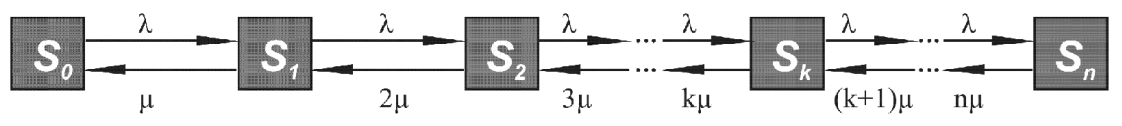

Fig. 3. System state graph with $n$ service posts with rejections 
one post and the cost of its maintenance during forced idle accepted as almost the same, then the net revenue of the repair section of the traction battery will be proportional to the magnitude $\mathrm{W}$, which will be determined by the following formula

$$
W=Q-M(n),
$$

where $M(n)$ is the number of posts forced to idle, which is calculated by the following formula

$$
M(n)=\sum_{k=0}^{n-1} p_{k}(n-k) .
$$

Furthermore, let us assume that the repair section of the traction battery can be mathematically presented as QS with expectation, and along with the introduced indicators of its efficiency, we will consider the following characteristics: $L_{s y s}$ is the average number of applications in the system; $T_{s y s}$ is the average time of EV stay at the polling station; $L_{s y s}$ is the average number of EV in the queue for service (queue length); $P_{\text {quе }}$ is probability that the EV will appear in the queue; $T_{\text {queu }}$ is the average time spent staying in the queue; $P_{\text {busy }}$ is probability that the repairing post is busy (fast loading rate).

Assuming that the queue length is unlimited, and service system has $n$ channels, the intensity of flows requests and service respectively $\lambda$ and $\mu$ (the graph of such a system states is shown in Fig. 4), then the boundary probabilities of $n$ - channel system states with unlimited queue and the indicated indicators are calculated according to the formulas given in Table 1 .

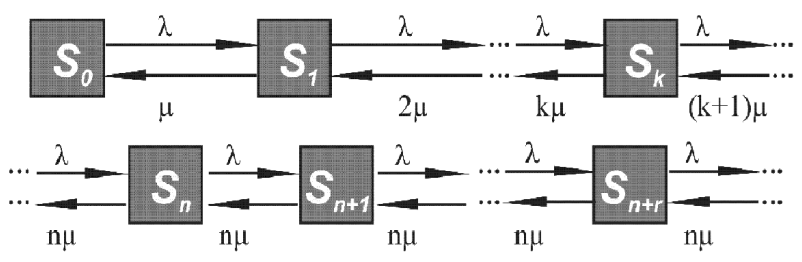

Fig. 4. A graph of multichannel $Q S$ with unlimited queue

In the task of rational traction battery diagnostic workshop organization let us assume that customers can expect their service for a long time and stay in the queue, as a criterion of optimality we will consider the minimum number of repair posts, in which the queue will not grow infinitely.

At the end, we will assume that the number of EV in the queue cannot exceed the given number, and in the case when all repair posts and places in the queue are occupied, EV leaves the site without service - it receives a deny. The formulas on which the parameters of the system and its performance indicators are calculated are given in the last column of Table. 1

For such a service system, we will place a task of finding the optimal number of queuing places for the services, which, with a fixed number of maintenance posts, provides minimal overall losses, both from idle and losses resulting from service refusals. The objective function of the task can be written as follows

$$
W(m)=c_{1} \lambda P_{r e j}+c_{2}(n-\bar{k})
$$

\begin{tabular}{|c|c|c|}
\hline Indicator & $\begin{array}{l}\text { Repair area of EV with service posts and } \\
\text { unlimited queue }\end{array}$ & $\begin{array}{c}\text { Repair area of EV with service posts and the } \\
\text { number of queues }\end{array}$ \\
\hline Limit probabilities & $\begin{array}{c}p_{0}=\left(\sum_{k=0}^{N} \frac{\rho^{k}}{k !}+\frac{\rho^{n+1}}{n !(n-\rho)}\right)^{-1} ; \\
p_{k}=\frac{\rho^{k}}{k !} \cdot p_{0}, k=\overline{1, n} \\
p_{n+r}=\frac{\rho^{n+r}}{n ! n^{r}} \cdot p_{0}, r=1,2, \ldots\end{array}$ & $\begin{array}{c}p_{0}=\left(\sum_{k=0}^{N} \frac{\rho^{k}}{k !}+\frac{\rho^{n+1}(1-\rho / n)^{m}}{n \cdot n !(1-\rho / n)}\right)^{-1} ; \\
p_{k}=\frac{\rho^{k}}{k !} \cdot p_{0}, k=\overline{1, n} \\
p_{n+r}=\frac{\rho^{n+r}}{n ! n^{r}} \cdot p_{0}, r=1,2, \ldots, m\end{array}$ \\
\hline $\begin{array}{l}\text { The probability that EV will appear in } \\
\text { the queue }\end{array}$ & $P_{\text {queu }}=\frac{\rho^{n+1}}{n !(n-\rho)} p_{0}$ & $P_{\text {queu }}=\frac{\rho^{n+1}}{n !(n-\rho)} p_{0}$ \\
\hline Refusal probability & $P_{\text {queu }}$ & $P_{r e j}=\frac{\rho^{n+m}}{n^{m} \cdot n !} p_{0}$ \\
\hline Absolute capacity & $A=\lambda Q$ & $A=\lambda Q=\lambda\left(1-\frac{\rho^{n+m}}{n^{m} \cdot n !} p_{0}\right)$ \\
\hline Relative capacity & $Q=1$ & $Q=1-P_{r e j}=1-\frac{\rho^{n+m}}{n^{m} \cdot n !} p_{0}$ \\
\hline The average number of EV in the queue & $L_{\text {queu }}=\frac{\rho^{n+1} p_{0}}{n \cdot n !\left(1-\frac{\rho}{n}\right)^{2}}$ & $L_{\text {queu }}=\frac{\rho^{n+1} p_{0}\left[1-\left(m+1-m \frac{\rho}{n}\right)\left(\frac{\rho}{n}\right)^{m}\right]}{n \cdot n !\left(1-\frac{\rho}{n}\right)^{2}}$ \\
\hline The average number of serviced EVs & $\bar{k}=\frac{\lambda}{\mu}=\rho$ & $\bar{k}=\rho\left(1-\frac{\rho^{n+m}}{n^{m} \cdot n !} p_{0}\right)$ \\
\hline The average number of EV in the system & $L_{s y s}=L_{\text {queu }}+\rho$ & $L_{s y s}=L_{\text {queu }}+\bar{k}$ \\
\hline $\begin{array}{l}\text { The average time spent by the EV at } \\
\text { the service }\end{array}$ & $T_{\text {queu }}=\frac{1}{\lambda} L_{s y s}$ & $T_{s y s}=\frac{1}{\lambda} L_{s y s}$ \\
\hline The average time spent in the queue & $T_{\text {quеи }}=\frac{1}{\lambda} L_{\text {quеи }}$ & $T_{\text {queu }}=\frac{1}{\lambda} L_{\text {queu }}$ \\
\hline
\end{tabular}

QS Performance Indicators 
where $c_{1}, c_{2}$ are losses due to unused maintenance or queue vacancies and failure to one client respectively.

The main stages of the technological process implementation of diagnosing, repairing and replacing the power supply elements of the traction battery, which are carried out at the repair section of the traction battery, are shown in Fig. 5.

The content of works, which are carried out at the repair section of the traction battery, as well as the combined values of cost and time spent on the repair work of the traction battery is empirically determined and is shown in Table 2.

Consequently, we will assume that the average service time for one EV is 10.7 hours, and the intensity of service $\mu=$ $=1 / 10.7$ ( $1 / \mathrm{hr}$.).
With the growth in the number of EVs we assume that the prospective demand will be $6-8$ cars per shift. Therefore, we will assume that the intensity of the flow of applications for diagnostics and repair of the traction battery is $\lambda=1 /(10 / 7)=$ $=0.7(1 / \mathrm{hr}$.), and the reduced intensity (load per one maintenance post) $\rho=0.7 /(1 / 10.7) \approx 7.5$.

It is calculated the minimum number of posts that must be arranged at the traction battery repair section, which would satisfy an average of $90 \%$ of clients. We will gradually increase the number of posts for repairing the traction battery and calculate all performance indicators for such a service system (1$6)$. At the same time, we find the optimal number of posts, which reaches the maximum net income, calculated by the (5).

The results of calculations are given in Table 3.

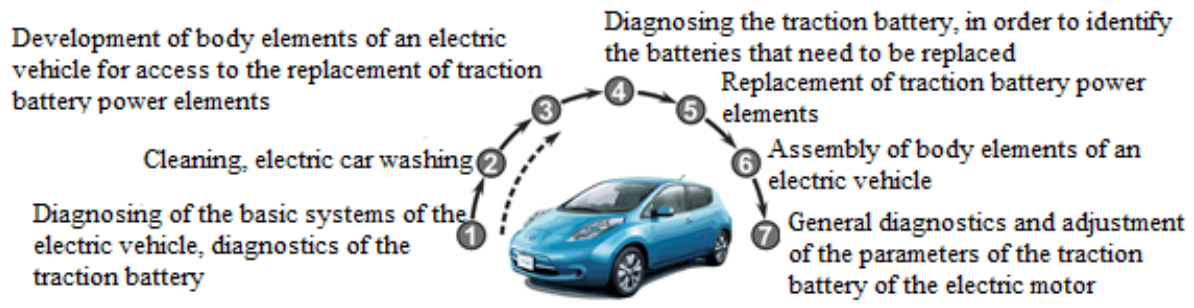

Fig. 5. The main stages of implementation of the technological process of repair and replacement of traction power elements of "Nissan Leaf"

Table 2

Consolidated values of cost and time spent on the repair of a traction battery

\begin{tabular}{|c|c|c|c|c|}
\hline No. stage & Contents of technological operations & Consumption time, hour & Price, UAH & Cost, $\$$ \\
\hline 1 & Diagnosis of basic EV systems, diagnostics of a traction battery & 0.7 & 1397 & 50 \\
\hline 2 & Cleaning, washing & 0.3 & 240 & 9 \\
\hline 3 & Disassembly of the main body elements for access to the replacement of batteries & 4 & \multirow[t]{4}{*}{11172} & \multirow[t]{4}{*}{400} \\
\hline 4 & Diagnosing the traction battery, in order to identify faults & 0.5 & & \\
\hline 5 & Replacement of power supply traction battery of EV & 0.5 & & \\
\hline 6 & Assembling of EV body elements & 4 & & \\
\hline 7 & General diagnosis and adjustment of the parameters of the traction battery of the EV & 0.7 & 1396 & 50 \\
\hline \multicolumn{2}{|l|}{ TOTAL } & 10.7 & 14205 & 509 \\
\hline
\end{tabular}

Table 3

Performance indicators of QS without queuing at $\rho=7.5$

\begin{tabular}{|c|c|c|c|c|c|c|c|}
\hline $\begin{array}{l}\text { Number of } \\
\text { repair posts, } \\
\text { posts }\end{array}$ & $\begin{array}{l}\text { Absolute } \\
\text { bandwidth }\end{array}$ & $\begin{array}{c}\text { Relative } \\
\text { bandwidth }\end{array}$ & $\begin{array}{l}\text { Probability } \\
\text { of a refusal }\end{array}$ & $\begin{array}{l}\text { The average number } \\
\text { of EVs that are being } \\
\text { repaired, EV }\end{array}$ & $\begin{array}{c}\text { The average } \\
\text { number of unused } \\
\text { posts, posts }\end{array}$ & $\begin{array}{c}\text { Value of the efficiency } \\
\text { (income) criterion, } \\
\text { unit }\end{array}$ & $\begin{array}{l}\text { Revenue per } \\
\text { unit repair } \\
\text { post }\end{array}$ \\
\hline$n$ & $A$ & $Q$ & P_no & $K \_$aver & Free_Canal & $W$ & $W / N$ \\
\hline 1 & 0.0824 & 0.118 & 0.882 & 0.882 & 0.118 & 0.764 & 0.764 \\
\hline 2 & 0.163 & 0.232 & 0.768 & 1.74 & 0.26 & 1.48 & 0.74 \\
\hline 3 & 0.24 & 0.343 & 0.657 & 2.57 & 0.432 & 2.14 & 0.712 \\
\hline 4 & 0.314 & 0.448 & 0.552 & 3.36 & 0.642 & 2.72 & 0.679 \\
\hline 5 & 0.383 & 0.548 & 0.452 & 4.1 & 0.899 & 3.2 & 0.64 \\
\hline 6 & 0.447 & 0.639 & 0.361 & 4.79 & 1.21 & 3.57 & 0.595 \\
\hline 7 & 0.505 & 0.721 & 0.279 & 5.4 & 1.6 & 3.81 & 0.544 \\
\hline 8 & 0.555 & 0.793 & 0.207 & 5.94 & 2.06 & 3.88 & 0.485 \\
\hline 9 & 0.597 & 0.853 & 0.147 & 6.39 & 2.61 & 3.78 & 0.42 \\
\hline 10 & 0.631 & 0.901 & 0.0991 & 6.75 & 3.25 & 3.5 & 0.35 \\
\hline 11 & 0.656 & 0.937 & 0.0632 & 7.02 & 3.98 & 3.03 & 0.276 \\
\hline 12 & 0.673 & 0.962 & 0.038 & 7.21 & 4.79 & 2.41 & 0.201 \\
\hline 13 & 0.685 & 0.979 & 0.0214 & 7.33 & 5.67 & 1.66 & 0.128 \\
\hline 14 & 0.692 & 0.989 & 0.0113 & 7.41 & 6.59 & 0.81 & 0.0579 \\
\hline 15 & 0.696 & 0.994 & 0.00562 & 7.45 & 7.55 & -0.104 & -0.007 \\
\hline 16 & 0.698 & 0.997 & 0.00262 & 7.47 & 8.53 & -1.06 & -0.0662 \\
\hline 17 & 0.699 & 0.999 & 0.00116 & 7.48 & 9.52 & -2.04 & -0.12 \\
\hline
\end{tabular}


Data analysis in Table 3 shows that the more posts in the repair area are, the greater the number of applications accepted to perform repair work is. Only with a significant increase in the number of posts increases the number of those who are forced to idle, and consequently, there increase unproductive costs of their maintenance. The function graph $W(n)$ is shown in Fig. 6. The optimum number of posts for repairing the traction battery $\mathrm{EV}$ is 8 .

To avoid an average of $90 \%$ of clients who apply for the service with intensity $\lambda=0.7$ per unit of time being refused, it is necessary that the site contain $n=10$ posts for diagnosis and repair.

It is also possible to determine an acceptable interval of change in the number of diagnostic and repair points of the traction battery of the EV at the site by finding reasonable limits for such competing economic indicators that characterize the service process, such as the probability of failure and the proportion of idle posts. The latter can be found by the formula

$$
X(n)=(n-\bar{k}) / n \text {. }
$$

Let us set the task of determining the number of service posts at the site, in which the probability of a customer refusal does not exceed the value $\alpha$, and the proportion of idle posts is not bigger $\beta$. Service levels $\alpha$ and $\beta$ are set for practical reasons. In Fig. 7, charts of two functions $y=P$ no $(n)$ and $y=X(n)$ are built. Levels of priority service are set $\alpha=0.15, \beta=0.33$. Obviously, the interval of change in the number of posts $n$ has a border set of 8.5 to 10 , therefore, it is enough to organize $n=9$ posts in order to reach a compromise solution in the task.

Now we calculate the performance indicators of the diagnostic and repair section of the traction battery of the EV, provided that it is presented as a $\mathrm{QS}$ with an unlimited queue. The parameters of service requests and service intensities are the same. Analyzing the corresponding formulas shown in Table 1 we can resume that the queue will not grow infinitely on condition $\rho / n<1$, namely $n>\rho=7.5$. Consequently, the minimum number of maintenance posts on the site $n_{\min }=8$. In Table 4 the computing results of the QS characteristics are given, considered that the number of the maintenance area $n_{\text {serv }}=4$, and the parking stops near the station $m$ gradually varies from 4 to 15 . Usually, the parking means to be a service part, because here EV can expect the release of service posts. The last column of Table 4 contains the value of the criterion of system efficiency, which takes into account the losses on the

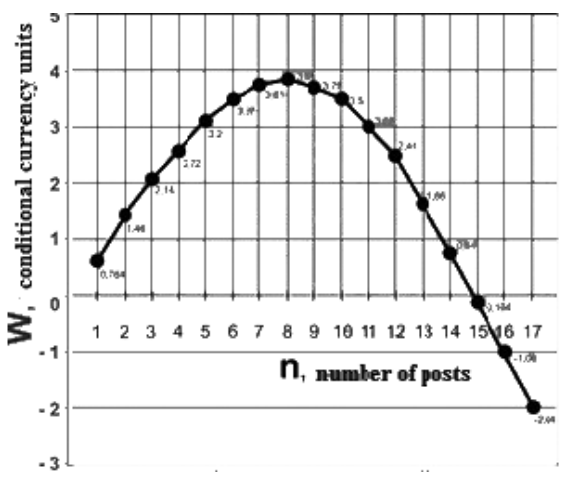

Fig. 6. Dependence of the income of the station $(W)$ on the number of available service posts (n)

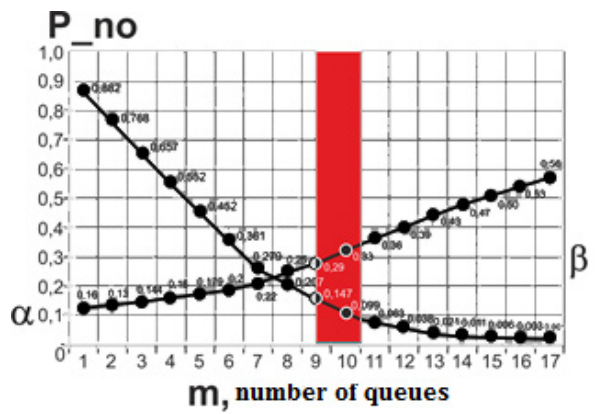

Fig. 7. Determination of acceptable change interval of service level

maintenance of repair posts and staying in the queue, and is given by the formula [15]

$$
\text { C_relativ }=\frac{1}{\lambda}\left(n_{\min }+m\right)+3 T_{\text {queu }} \text {. }
$$

Consequently, the results of calculations indicate that the probability of idle posts is almost zero even with $m=4$. When $m=7$ the probability of occurrence of a queue decreases significantly $P_{-} q u e$. In addition, the value of the optimality criterion for this $m$ is the smallest. Function graph $y=C$ relativ $(m)$

Table 4

Indicators of the effectiveness of QS with unlimited queues at $\rho=7.5$

\begin{tabular}{|c|c|c|c|c|c|c|c|}
\hline $\begin{array}{c}\text { Number of } \\
\text { places in the } \\
\text { parking lot, } \\
\text { places }\end{array}$ & $\begin{array}{c}\text { Total number } \\
\text { of service } \\
\text { channels, } \\
\text { channels }\end{array}$ & $\begin{array}{c}\text { The average } \\
\text { amount of EV } \\
\text { that is being } \\
\text { repaired, EV }\end{array}$ & $\begin{array}{c}\text { The } \\
\text { probability of } \\
\text { the station } \\
\text { being idle }\end{array}$ & $\begin{array}{c}\text { Probability } \\
\text { for EV to get } \\
\text { to the queue }\end{array}$ & $\begin{array}{c}\text { The average } \\
\text { number of EVs } \\
\text { in a queue, EV }\end{array}$ & $\begin{array}{c}\text { Average waiting } \\
\text { time in the } \\
\text { queue, } h\end{array}$ & $\begin{array}{c}\text { Losses for keeping } \\
\text { posts and staying } \\
\text { in queue, mind. } \\
\text { money unit }\end{array}$ \\
\hline$m$ & $N$ & K_aver & $p 0$ & $P_{-} q u e$ & $L_{\text {qque }}$ & $T_{\text {_que }}$ & C_relativ \\
\hline 4 & 8 & 7.49 & 0.000209 & 0.752 & 11.8 & 16.9 & 62 \\
\hline 5 & 9 & 7.49 & 0.000416 & 0.421 & 2.51 & 3.59 & 23.6 \\
\hline 6 & 10 & 7.49 & 0.0005 & 0.228 & 0.909 & 1.3 & 18.2 \\
\hline 7 & 11 & 7.49 & 0.000534 & 0.119 & 0.373 & 0.532 & 17.3 \\
\hline 8 & 12 & 7.49 & 0.000549 & 0.0593 & 0.158 & 0.225 & 17.8 \\
\hline 9 & 13 & 7.49 & 0.000555 & 0.0283 & 0.0667 & 0.0953 & 18.9 \\
\hline 10 & 14 & 7.49 & 0.000557 & 0.0129 & 0.0277 & 0.0395 & 20.1 \\
\hline 11 & 15 & 7.49 & 0.000558 & 0.00558 & 0.0111 & 0.0159 & 21.5 \\
\hline 12 & 16 & 7.49 & 0.000558 & 0.0023 & 0.00433 & 0.00619 & 22.9 \\
\hline 13 & 17 & 7.49 & 0.000559 & 0.000909 & 0.00162 & 0.00232 & 24.3 \\
\hline 14 & 18 & 7.49 & 0.000559 & 0.000342 & 0.000586 & 0.000837 & 25.7 \\
\hline 15 & 19 & 7.49 & 0.000559 & 0.000123 & 0.000203 & 0.000291 & 27.1 \\
\hline
\end{tabular}




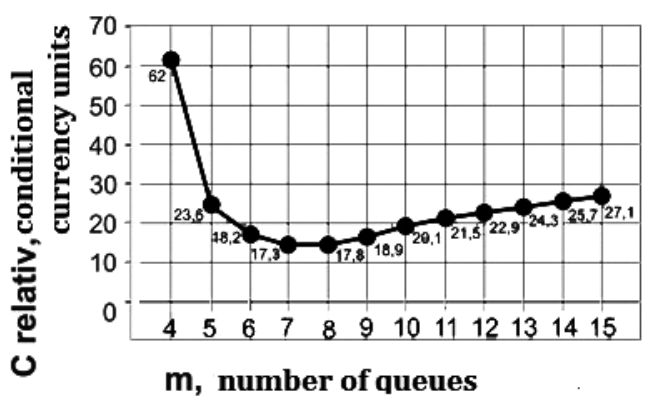

Fig. 8. Chart of the dependence of losses on the maintenance and EV parking capacity $(n=4)$

is presented in Fig. 8. With increasing waiting places in the parking lot from 4 to 7 , the probability of getting to the queue from the client decreases from 0.752 to 0.37 . And if there are 8 seats in the parking lot, about $10 \%$ of customers get to the queue. In this case, the average time of finding the EV in the queue is only 0.225 (13-14 minutes).

Results of calculations of the work efficiency indicators provided they are considered as multichannel $(n=4)$ service systems with expectations at different queue lengths are shown in Table 5. According to these data, we can draw the following conclusions. In the case when the intensity of the applications flow for the repair of traction battery almost twice exceeds the number of service posts and the site, and the service itself lasts about 10 hours, the probability of the downtime of the site is almost zero, and the probability of the client getting to the queue is almost 0.5 , that is, every second client will wait for being provided a service. The waiting time in a queue depends on the number of $m$ places in a queue and increases with increasing $m$. Thus, the capacity of the system is limited by the number of $N=m+n$, then the effective intensity of applications for the repair of the traction battery of the EV appeared below the given and increases with increasing $m$ from 0.314 to 0.374 . You can choose the optimal number of queues for reasonable (acceptable) waiting times in a queue. For example, if you limit this time to a value of 5-6 hours, it is enough to limit the length of the queue to 5 places.

Of course, the rational organization problem solution of the area for the diagnosis and repair of the traction battery can be carried out using the usual method of analogy, based on a certain system of planned and preventive repair and maintenance of similar electrical equipment. Moreover, the prototype can be considered using already existing models of such stations for the repair of cars with an internal combustion engine. However, there are several differences between the specifics of the conventional cars operation and EVs. One of the most important is the inability to ensure the reliability of the aggregates, in particular the traction battery, after the maintenance, and therefore, to predict the behavior of EV in the future. Therefore, it is impossible to predict the probable failure of units and systems that have a significant effect on traffic safety. The application of models and methods of QS to calculate the technical and economic parameters of the production capacity of the traction battery repair station is, though difficult, but also a very productive approach. This approach allows taking into account the stochastic nature of the needs for servicing the traction battery and requires the specialists to organize the work of the appropriate basic training fore service staff.

\section{Conclusions.}

1. With the use of the systematic approach, the EV market in Ukraine, the dynamics of demand for EVs in the last three years have been researched. The information on the problems associated with the operation of the EV has been collected and analyzed, and the most common problems have been found. The estimation of the duration of the process of diagnosing, repairing and replacing the traction batteries as well as the cost of basic operations, has been carried out.

Performance indicators for QS with limited queue at $\rho=7.5$

\begin{tabular}{|c|c|c|c|c|c|c|c|c|c|}
\hline 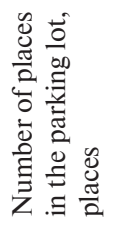 & 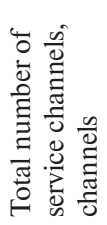 & 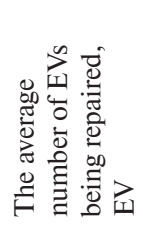 & 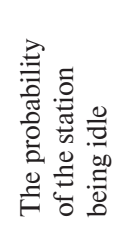 & 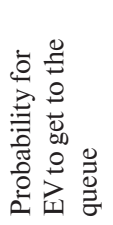 & 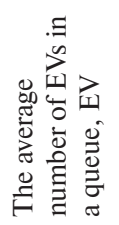 & 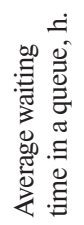 & 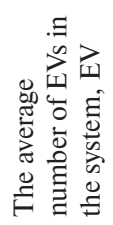 & 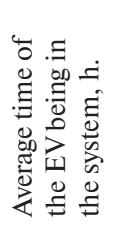 & 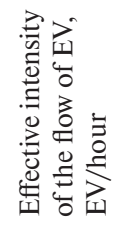 \\
\hline$m$ & $N$ & K_aver & $p 0$ & P_no & L_que & T_que & L_sys & $T$ sys & lamda_eff \\
\hline 0 & 4 & 3.36 & 0.00421 & 0.552 & 0 & 0 & 3.36 & 4.8 & 0.314 \\
\hline 1 & 5 & 3.68 & 0.00207 & 0.508 & 0.508 & 0.726 & 4.19 & 5.99 & 0.344 \\
\hline 2 & 6 & 3.84 & 0.00106 & 0.488 & 1.24 & 1.76 & 5.07 & 7.25 & 0.359 \\
\hline 3 & 7 & 3.92 & 0.000554 & 0.477 & 2.08 & 2.97 & 5.99 & 8.56 & 0.366 \\
\hline 4 & 8 & 3.96 & 0.000293 & 0.472 & 2.98 & 4.26 & 6.94 & 9.91 & 0.37 \\
\hline 5 & 9 & 3.98 & 0.000155 & 0.469 & 3.93 & 5.61 & 7.91 & 11.3 & 0.372 \\
\hline 6 & 10 & 3.99 & $8.27 \mathrm{e}-05$ & 0.468 & 4.9 & 7 & 8.89 & 12.7 & 0.373 \\
\hline 7 & 11 & 3.99 & $4.41 \mathrm{e}-05$ & 0.467 & 5.88 & 8.4 & 9.87 & 14.1 & 0.373 \\
\hline 8 & 12 & 4 & $2.35 \mathrm{e}-05$ & 0.466 & 6.87 & 9.81 & 10.9 & 15.5 & 0.373 \\
\hline 9 & 13 & 4 & $1.26 \mathrm{e}-05$ & 0.466 & 7.86 & 11.2 & 11.9 & 16.9 & 0.374 \\
\hline 10 & 14 & 4 & $6.71 \mathrm{e}-06$ & 0.466 & 8.86 & 12.7 & 12.9 & 18.4 & 0.374 \\
\hline 11 & 15 & 4 & $3.58 \mathrm{e}-06$ & 0.466 & 9.86 & 14.1 & 13.9 & 19.8 & 0.374 \\
\hline 12 & 16 & 4 & $1.91 \mathrm{e}-06$ & 0.466 & 10.9 & 15.5 & 14.9 & 21.2 & 0.374 \\
\hline 13 & 17 & 4 & $1.02 \mathrm{e}-06$ & 0.466 & 11.9 & 16.9 & 15.9 & 22.6 & 0.374 \\
\hline 14 & 18 & 4 & $5.45 \mathrm{e}-07$ & 0.466 & 12.9 & 18.4 & 16.9 & 24.1 & 0.374 \\
\hline 15 & 19 & 4 & $2.91 \mathrm{e}-07$ & 0.466 & 13.9 & 19.8 & 17.9 & 25.5 & 0.374 \\
\hline
\end{tabular}


2. The section for repairing the traction battery of the EV is presented as multichannel QS, on the assumption that the flow of requests for the diagnosis and repair of the traction battery of the EV is Poissonian, and the random process is Markov's. The task of rational organization of the section for diagnosing and repairing the traction battery of the EV is solved by determining the minimum number of repair posts, in which the queue will not grow infinitely (if customers can wait for being provided a service for a long time and do not leave a queue).

3. The estimated number of repair posts for the repair section of the traction battery, which will allow organizing maintenance of clients effectively, minimizing the total economic losses from simple equipment and refusals for applications requiring repair work.

4. In the conditions prevailing in the EV market in the region, during the organization of the traction battery repair section, there should be 7-9 positions of simultaneous customer service, including waiting room in the parking lot.

5. The proposed method for determining the production capacity of the traction battery repair station can be used solving issues related to the choice and rational placement of technological equipment in the design or modernization of service stations.

\section{References.}

1. Hlushkova, D. B., Hrinchenko, O. D., Kostina, L. L., \& Cholodov, A. P. (2018). The choice of material for strengthening of leading edges of working blades of steam turbines. Problems of Atomic Science and Technology, 113(1), 181-188.

2. Franchuk, V.P., Ziborov, K.A., Krivda, V.V., \& Fedoriachenko, S. O. (2018),. Influence of thermophysical processes on the friction properties of wheel - rail pair in the contact area. Naukovyi Visnyk Natsionalnoho Hirnychoho Universytetu, 2, 46-52, DOI: 10.29202/nvngu/2018-2/7.

3. Raksha, S. V., Anofriev, P. G., Bohomaz, V. M., \& Kuropiatnyk, O. S. (2019) Mathematical and S-models of cargo oscillations during movement of bridge crane. Naukovyi Visnyk Natsionalnoho Hirnychoho Universytetu, 2, 108-115, DOI: 10.29202/nvngu/2019-2/16.

4. Peng-Yong Kong, \& Karagiannidis, K. (2016). Charging Schemes for Plug-In Hybrid Electric Vehicles in Smart Gride: A Survey. IEEE Access Journal, 1-29. DOI: 10.1109/ACCESS.2016.2614689.

5. Pivnyak, G., Dychkovskyi, R., Bobyliov, O., Cabana, E.C., \& Smoliński, A. (2018). Mathematical and geomechanical model in physical and chemical processes of underground coal gasification. Solid State Phenomena, 277, 1-16. DOI: 10.4028/ www.scientific.net/SSP.277.1.

6. Sparacino, A.R., Grainger, B. M., Kerestes, R.J., \& Reed, G. F. (2012). Design and Simulation of a DC Electric Vehicle Charging Station Connected to a MVDC Infrastructure. Energy Conversion Congress and Exposition (ECCE) (pp. 1168-1175). DOI: 10.1109/ECCE.2012.642685.

7. Kravets, V.V., Kravets, T. V., \& Kharchenko, A.V. (2009). Using quaternion matrices to describe the kinematics and nonlinear dynamics of an asymmetric rigid body. International Applied Mechanics, 45(2), 223-231.

8. Kravets, V. V., Sakhno, V., Bas, K., \& Kravets, V. I. (2018). Program spatial movement of high-speed vehicles. IOP Conference. Series: Materials Science and Engineering, 383(1), 012032, DOI: 10.1088/1757-899X/383/1/012032.

9. He, S. Y., Kuo, Y.-H., \& Wu, D. (2016). Incorporating in situational and spatial factors in these lection of the optimal locations of public electric vehicle charging facilities: A case study of Beijing, China. Transportation Research Part C: Emerging Technologies, 67, 131-148. DOI: 10.1016/j.trc.2016.02.003. 10. Ziborov, K., \& Fedoriachenko, S. (2014), The frictional work in pair wheel-rail in case of different structural scheme of mining rolling stock. Progressive Technologies of Coal, Coalbed Methane, and Ores Mining, 517-521.
11. Deryugin, O. V., \& Cheberyachko, S. I. (2015). Substantiation of the choice of a truck on the criterion of minimizing the psychophysiological load on the driver. Vostochno-Evropeiskii zhurnal peredovykh tekhnologii, 3(75), 15-22.

12. Chaofei Lu, Xi'an Sun, \& Jingru Zhao (2015). The optimization research on the queuing system in highway long-distance bus terminal small express. International Conference on Logistics, Informatics and Service Sciences (LISS) (pp. 1-4), Barcelona. DOI: 10.1109/LISS.2015.7369803.

13. Matsyuk, I., \& Shlyahov, E. (2015), The research of plane link complexstructure mechanisms by vector algebra methods. Eastern-European Journal of Enterprise Technologies, 3(7), 34-38. 14. Golinko, V. I., Cheberyachko, S. I., Yavorskaya, E. A., \& Cheberyachko, Y.I. (2016). Analysis of protective value of dust-fighting respirators and its effect on dust burden of miners. Gornyi Zhurnal, 3, 76-80. DOI 10.17580/gzh.2016.03.16. 15. Laukhin, D. V., Beketov, O. V., Rott, N. O., Tyuterev, I. A., Ivantsov, S. V., \& Laukhin, V. D. (2017). The Analysis of Interrelation between Kinetics of Propagation of Plastic Deformation and Initiation of Ductile Fracture. Metallofiz. Noveishie Tekhnol., 39(10), 1335-1343. DOI: 10.15407/mfint.39.10.1335. 16. Beshta, A., Aziukovskyi, O., Balakhontsev, A., \& Shestakov, A. (2017). Combined power electronic converter for simultaneous operation of several renewable energy sources. 2017 International Conference on Modern Electrical and Energy Systems (MEES) (pp. 236-239), Kremenchuk. DOI: 10.1109/MEES.2017.8248898.

17. Berezshnaya, O. V., Gribkov, E. P., Borovik, P. V., \& Kassov, V. D. (2019). The Finite Element Modulation of Thermostressed State of Coating Formation at Electric Contact Surfacing of "Shaft" Type Parts. Advances in Materials Science and Engineering, 1-18. Article ID 7601792. DOI: $10.1155 / 2019 / 7601792$.

18. Koišová, E., Grmanová, E., \& Habánik, J. (2018). Regional disparities in financing innovations in small and medium-sized enterprises. Journal of International Studies, 11(3), 124-136. DOI: 10.14254/2071-8330.2018/11-3/11.

19. Syrotkina, O., Alekseyev, M., \& Aleksieiev, O. (2017). Evaluation to determine the efficiency for the diagnosis search formation method of failures in automated systems. EasternEuropean Journal of Enterprise Technologies, 4(9(88)), 59-68. DOI: $10.15587 / 1729-4061.2017 .108454$.

20. Diachenko, G. G., \& Aziukovskyi, O. O. (2017). Investigation of the Process Parameters Influence on the Energy Efficiency of an Induction Motor under Model Predictive Control GRAMPC. Mechanics, Materials Sicence \& Engineering, 12, 124-132. ISSN 2412-5954.

\section{Визначення виробничої потужності дільниці ремонту тягової акумуляторної батареї електромобіля}

\section{Л. С. Коряшкіна ${ }^{1}$, О. В. Дерюгін ${ }^{1}$, С. О. Федоряченко ${ }^{1}$, С. I. Чеберячко ${ }^{1}$, М. А. Весела ${ }^{2}$}

1 - Національний технічний університет „Дніпровська політехніка“, м. Дніпро, Україна, e-maill: serg. fedoryachenko@gmail.com

2 - Харківський національний автомобільно-дорожній університет, м. Харків, Україна

Мета. Забезпечення ефективного функціонування дільниці з діагностування й ремонту тягової акумуляторної батареї (АКБ) електромобіля (ЕМ) за рахунок визначення техніко-економічних показників виробничої потужності підприємства.

Методика. Моделювання роботи дільниці ремонту тягової АКБ ЕМ здійснюється з використанням основних положень теорії масового обслуговування, теорії графів. При розрахунках імовірнісно-часових характе- 
ристик і визначенні виробничої потужності дільниці залучалися методи математичної статистики й теорії ймовірностей.

Результати. Із використанням системного підходу досліджено ринок ЕМ в Україні, динаміка попиту на ЕМ за останні три роки. Проведено збір і аналіз інформації щодо проблем, пов'язаних з експлуатацією ЕМ, і виявлені найбільш поширені з них. Емпіричним шляхом отримана оцінка тривалості процесу ремонту й заміни елементів живлення тягової АКБ ЕМ, а також вартість основних операцій. Дільниця ремонту тягової АКБ ЕМ представлена як багатоканальна система масового обслуговування, у припущенні, що потік заявок на діагностування й ремонт тягової АКБ ЕМ є пуассонівським, а випадковий процес є марківським. Розв'язана задача раціональної організації дільниці ремонту тягової АКБ ЕМ за рахунок визначення мінімальної кількості постів ремонту, за якої черга не буде зростати нескінченно (якщо клієнти можуть очікувати на своє обслуговування досить довго й не залишають чергу). Розрахована кількість ремонтних постів для дільниці ремонту тягової АКБ ЕМ, що дозволить в існуючих умовах ефективно організувати технічне обслуговування клієнтів, мінімізуючи сумарні економічні втрати від простою технологічного обладнання й відмов на заявки на проведення ремонтних робіт.

Наукова новизна. Застосування моделей і методів теорії масового обслуговування для розрахунку техніко-економічних показників виробничої потужності дільниці ремонту тягової АКБ ЕМ дозволило врахувати стохастичний характер потреб у ремонті агрегату, що розглядається, і визначити оптимальні значення тих характеристик, що забезпечують ефективну роботу дільниці з ремонту тягової АКБ ЕМ.

Практична значимість. Запропонована методика з визначення виробничих потужностей дільниці ремонту тягової АКБ ЕМ може бути використана при вирішенні питань, пов'язаних із вибором і раціональним розміщенням технологічного обладнання при проектуванні або модернізації станції технічного обслуговування (СТО), а також при організації пункту заміни заряджених тягових АКБ для ЕМ, що мають, у тому числі, і конструктивну пристосованість для поповнення енергії живлення.

Ключові слова: електромобіль, виробнича потужність, дільниия ремонту, система масового обслуговування

\section{Определение производственной мощности участка ремонта тяговой аккумуляторной батареи электромобиля}

\section{Л. С. Коряшкина ${ }^{1}$, О. В. Дерюгин ${ }^{1}$, С.А. Федоряченко ${ }^{1}$, С. И. Чеберячко ${ }^{1}$ М. А. Веселая ${ }^{2}$}

1 - Национальный технический университет „Днепровская политехника“, г. Днепр, Украина, e-maill: serg. fedoryachenko@gmail.com

2 - Харьковский национальный автомобильно-дорожный університет, г. Харьков, Украина
Цель. Обеспечение эффективного функционирования участка по диагностике и ремонту тяговой аккумуляторной батареи (АКБ) электромобиля (ЭМ) за счет определения технико-экономических показателей производственной мощности предприятия.

Методика. Моделирование работы участка ремонта тяговой АКБ ЭМ осуществляется с использованием основных положений теории массового обслуживания, теории графов. При расчетах вероятностно-временных характеристик и определении производственной мощности участка применялись методы математической статистики и теории вероятностей.

Результаты. С использованием системного подхода исследован рынок ЭМ в Украине, динамика спроса на ЭМ за последние три года. Проведен сбор и анализ информации по проблемам, связанным с эксплуатацией ЭМ, выявлены наиболее распространенные из них. Эмпирическим путем получена оценка продолжительности процесса ремонта и замены элементов питания тяговой АКБ ЭМ, а также стоимость основных операций. Участок ремонта тяговой АКБ ЭМ представлен как многоканальная система массового обслуживания в предположении, что поток заявок на диагностирование и ремонт тяговой АКБ ЭМ является пуассоновским, а случайный процесс является марковским. Решена задача рациональной организации участка ремонта тяговой АКБ ЭМ за счет определения минимального количества постов ремонта, при которой очередь не будет расти бесконечно (если клиенты могут ожидать достаточно долго и не оставляют очередь). Определено количество ремонтных постов для участка ремонта тяговой АКБ ЭМ, позволяющее в существующих условиях эффективно организовать техническое обслуживание клиентов, минимизируя суммарные экономические потери от простоя технологического оборудования и отказов на заявки на проведение ремонтных работ.

Научная новизна. Применение моделей и методов теории массового обслуживания для расчета технико-экономических показателей производственной мощности участка ремонта тяговой АКБ ЭМ позволило учесть стохастический характер потребностей в ремонте этого агрегата, и определить оптимальные значения тех характеристик, которые обеспечивают эффективную работу участка по ремонту тяговой АКБ ЭМ.

Практическая значимость. Предложенная методика по определению производственных мощностей участка ремонта тяговой АКБ ЭМ может быть использована при решении вопросов, связанных с выбором и рациональным размешением технологического оборудования при проектировании или модернизации станции технического обслуживания (СТО), а также при организации пункта замены заряженных тяговых АКБ для ЭМ, которые имеют, в том числе, и конструктивную приспособленность для пополнения энергии питания.

Ключевые слова: электромобиль, производственная мощность, участок ремонта, система массового обслуживания

Рекомендовано до публікації докт. техн. наук В. В. Процівом. Дата надходження рукопису 12.12.18. 